\title{
Evaluation of the Effects of Administration of Aqueous Root Extract of Chrysophylum albidum on Fertility in Male Wistar Albino Rats
}

\section{Oigbochie Vennessa Eseohe ${ }^{1, a}$, Osarumwense Marvellous Oghosa ${ }^{1, b}$, Odiase Daniel Enoghense ${ }^{1, \mathrm{c}}$ and Omage Kingsley ${ }^{2, \mathrm{~d},{ }^{*}}$}

\author{
${ }^{1}$ Department of Anatomy, School of Basic Medical Sciences, College of Medical Sciences, \\ University of Benin, Edo State, Nigeria \\ ${ }^{2}$ Department of Biochemistry, College of Basic Medical Sciences, Igbinedion University, Okada, \\ Edo State, Nigeria \\ aeseohe.oigbochie@uniben.edu, ${ }^{\mathrm{b}}$ marvellousrichards@gmail.com, ${ }^{\mathrm{c}}$ daniel.odiase@uniben.edu, \\ domagekingsley@yahoo.com
}

Keywords: Chrysophyllum albidium; Root extract; Sperm motility; Sperm morphology; Fertility; Epididymis.

\begin{abstract}
This study evaluated the effects of administration of aqueous root extracts of Chrysophyllum albidum on sperm characteristics and histology of the epididymis of experimental rats. Forty-five adult male Wistar rats were randomized into 3 groups of 15 rats each. Each group was further randomized into 3 subgroups of 5 rats each, according to the dose and duration of extract administration. Administration of the extract for 8 weeks resulted in significant $(\mathrm{P}<0.05)$ decreases in the number of progressively motile sperm cells of rats in subgroup B3 $(75.00 \pm$ $0.00 \%)$ and C3 $(75.00 \pm 0.00 \%)$ as compared with the control subgroup A3 $(80.00 \pm 0.00 \%)$. Also, there were significant $(\mathrm{p}<0.05)$ decreases in the number of morphologically normal sperm cells of rats in test subgroups B3 treated with low dose and C3 treated with high dose. However, there were no significant histological changes in the epididymis of the experimental rats in all the treated groups, at different doses and duration. Administration of aqueous root extract of Chrysophyllum albidium at varying doses and time duration negatively affects sperm motility and morphology which may compromise the fertility of the experimental rats.
\end{abstract}

\section{Introduction}

In Africa, thousands of plants have been used and are still been used for medicinal purposes. The use of these medicinal plants for therapeutic purposes transcends all cultures and traditions. It is a vital approach that is easily accessible to the populace and at little or no cost. An important aspect of reproductive health is the regulation of fertility, i.e. contraception and management of infertility [1]. Over the years, there has been an increase in the search for male contraceptives of natural origin with the lowest possible side effect [2]. Although there are many contraceptive agents with varying side effects, several medicinal plants have been shown to exhibit male contraceptive properties by either suppressing spermatogenesis or by spermicidal action [3].

Medicinal plants are herbal remedies for the treatment and management of different ailments [4]. Chrysophyllum albidum, also known as White Star Apple or African Star Apple, is a popular medicinal plant which belongs to the family Sapotaceae. Phytochemical analyses show that Chrysophyllum albidum contains alkaloids, tannin, saponin, phenol and flavonoid [5]. The different parts of the plants; leaves, bark, seeds and fruits, has its own medicinal value. The leaf is used as a skin moisturizer and for the treatment of skin eruption, stomach ache and diarrhoea [6]. The bark decoction is often used in the treatment of diseases such as yellow fever and malaria [7]. Onyeka et al. [8] reported that the root bark has anti-fertility effects while Adewoye et al. [9] reported that the stem bark has antimicrobial effects. The seed cotyledons are used as ointments in the treatment of vaginal and skin infections [10]. However, the extensive, long-term usage of herbal products without proper monitoring has brought about a number of health related problems like infertility, a 
common problem affecting most couples all over the world [11]. Thus, this study was carried out to evaluate the possible dose and duration- dependent effects of aqueous Chrysophyllum albidum roots extract on sperm characteristics and epididymis of adult male Wister rats.

\section{Materials and Methods}

\section{Plant material and extract preparation}

The root bark of Chrysophyllum albidum was obtained from a local garden in Benin City and authenticated by a plant taxonomist in the Department of Plant Biology and Biotechnology, University of Benin. The root bark was properly washed, air dried at room temperature for few days and oven dried, after which it was pulverized into fine powder using a mechanical grinder. The powder was weighed and about $800 \mathrm{~g}$ of it was macerated with 1.5 litres of distilled water for 24 hours. The mixture was stirred and shaken continuously using a magnetic stirrer and afterwards filtered using Whatman No 1 filter paper. The filtrate was concentrated using a rotary evaporator.

\section{Experimental animals}

Forty-five (45) adult male Wistar rats weighing between $200 \mathrm{~g}$ and $250 \mathrm{~g}$ were used for this study. The experimental rats were bred in the animal holdings of the Department of Anatomy, School of Basic Medical Sciences, University of Benin, Benin City. The rats were allowed to acclimatize to the animal house for two weeks with free access to feed (growers mash from Bendel Feed Flour Mill Ltd) and water. They were maintained a on a 12 hour light and dark cycle and cared for in accordance with the guidelines of the Research Ethics Committee of the College of Medical Sciences, University of Benin, Benin City.

\section{Experimental design}

The experimental animals were randomized into 3 groups of 15 rats each and treated as follows:

Group A: The rats in this group served as control and were given normal diet and distilled water.

Group B: Aqueous extract of Chrysophyllum albidum was administered orally at $250 \mathrm{mg} / \mathrm{kg}$ (low dose) to the rats in this group.

Group C: Aqueous extract of Chrysophyllum albidum was administered orally at $500 \mathrm{mg} / \mathrm{kg}$ (high) to the rats in this group.

Each group was further subdivided (randomized) into 3 subgroups, with 5 rats each, according to the duration of administration of the extract as follows;

Grouping of experimental rats according to dose and duration of administration

\begin{tabular}{|c|c|c|c|c|c|c|c|c|c|}
\hline \multirow{2}{*}{$\begin{array}{c}\text { Main } \\
\text { groups }\end{array}$} & \multicolumn{3}{|c|}{ Control } & \multicolumn{3}{c|}{ Low Dose } & \multicolumn{3}{c|}{ High Dose } \\
\cline { 2 - 10 } & \multicolumn{3}{|c|}{ A } & \multicolumn{3}{c|}{ B } & \multicolumn{3}{c|}{ C } \\
\hline $\begin{array}{c}\text { Sub } \\
\text { groups }\end{array}$ & A1 & A2 & A3 & B1 & B2 & B3 & C1 & C2 & C3 \\
\cline { 2 - 10 } & 4 wks & 6 wks & 8 wks & 4 wks & 6 wks & 8 wks & 4 wks & 6 wks & 8wks \\
\hline
\end{tabular}

\section{Body and organ weight measurements}

The body weights of the rats were taken weekly while their organ weights were taken at the end of the experiment (after sacrifice) using a Top loader weighing balance. The differences in body weights were determined.

\section{Determination of $\mathbf{L D}_{\mathbf{5 0}}$}

The $\mathrm{LD}_{50}$ of Chrysophyllum albidum root bark as determined by Adewoye et al. [12] is $1850 \mathrm{mg} / \mathrm{kg}$ body weight. 


\section{Extract administration and duration}

The extract was administered orally and daily using an orogastric tube. Subgroups A1, B1 and $\mathrm{C} 1$ were given extract for 4weeks (28days), subgroups A2, B2, and C2 for 6weeks (42 days) while A3, B3 and C3 were given extract for 8weeks (56days).

\section{Sacrifice of animals}

At the end of each experimental period (i.e. at week 4, week 6 and week 8), a transverse incision was made through the ventral wall of the abdomen of each rat under slight chloroform anaesthesia. The epididymis were excised and fixed in Bouin's fluid in readiness for routine histological procedure. Sperm cells were collected from the vas deferens of the sacrificed rats, Sperm analysis were conducted immediately the sperm cells were excised from the vas deferens.

\section{Sperm analysis}

Sperm cells were collected from the epididymis during the sacrifice by litigating the extremities of the vas deferens to a length of about $36 \mathrm{~nm}$ and $6 \mu 1$ normal saline was added to the litigated extremities. The litigated extremities of the vas deferens were placed on a Petri dish and teased to allow the sperm cells diffuse. The section was viewed under the microscope for sperm motility. The results were evaluated using two variables as stated below:

1) Progressive (or qualitative) motility, usually expressed in terms of mean Progressive motility score - Progressive Motility (PM), Non Progressive Motility (NPM), Immotile (IM).

2) Percentage of motile spermatozoa.

Vitality test was carried out to evaluated living and dead spermatozoa. This was done with a supra-vital stain (eosin Y).

Sperm Morphology was evaluated by making a smear of sperm cell on a grease free slide and allowing it to air dry. The sample was stained using the Bryan-Leishman technique [20] for 30 mins. The smear was rinsed with distilled water, bloated and finally air dried. It was then viewed under oil immersion objective lens. The scores or results were recorded as a percentage of normal and abnormal sperm cells. Normal sperm shows a normal sperm characteristic of head, axoneme, middle piece and a tail. Abnormal sperm cells were characterized by large heads; headless, tailless, bulgy mid-piece curved tail and joined head.

\section{Histological procedure}

The tissues were fixed in Bouin's fluid for less than 24hours. The tissues were then processed via paraffin wax embed method of Drury and Wallington [13] and Scheehan and Brapchak [14].

\section{Haematoxylin and eosin staining method}

Staining of the tissues was done using H \& E dyes (Haematoxylin and Eosin dyes).

\section{Photomicrography}

The sections were examined under a Leica DM750 research microscope with a digital camera Leica ICC50 attached. Digital photomicrographs of the tissues section were taken at various magnifications.

\section{Statistical analysis}

The data generated were analyzed using descriptive and inferential statistics. Data were presented as Mean \pm Standard Error of Means (S.E.M). Significance difference of means was determined using one-way analysis of variance (ANOVA) at $95 \%$ confidence interval. Least Square Difference (LSD) and post-hoc tests were carried out for all groups. All statistical analysis was carried out using Statistical Package for Social Sciences (SPSS) (version 17) manufactured by International Business Machine Corporation (IBM) in Armonk, New York. 


\section{Results}

The effects of administration of aqueous root extracts of Chrysophyllum albidum on the body weights, organ weights, sperm characteristics and histology of the epididymis of the experimental rats are as shown below;

\section{Effect on body weight}

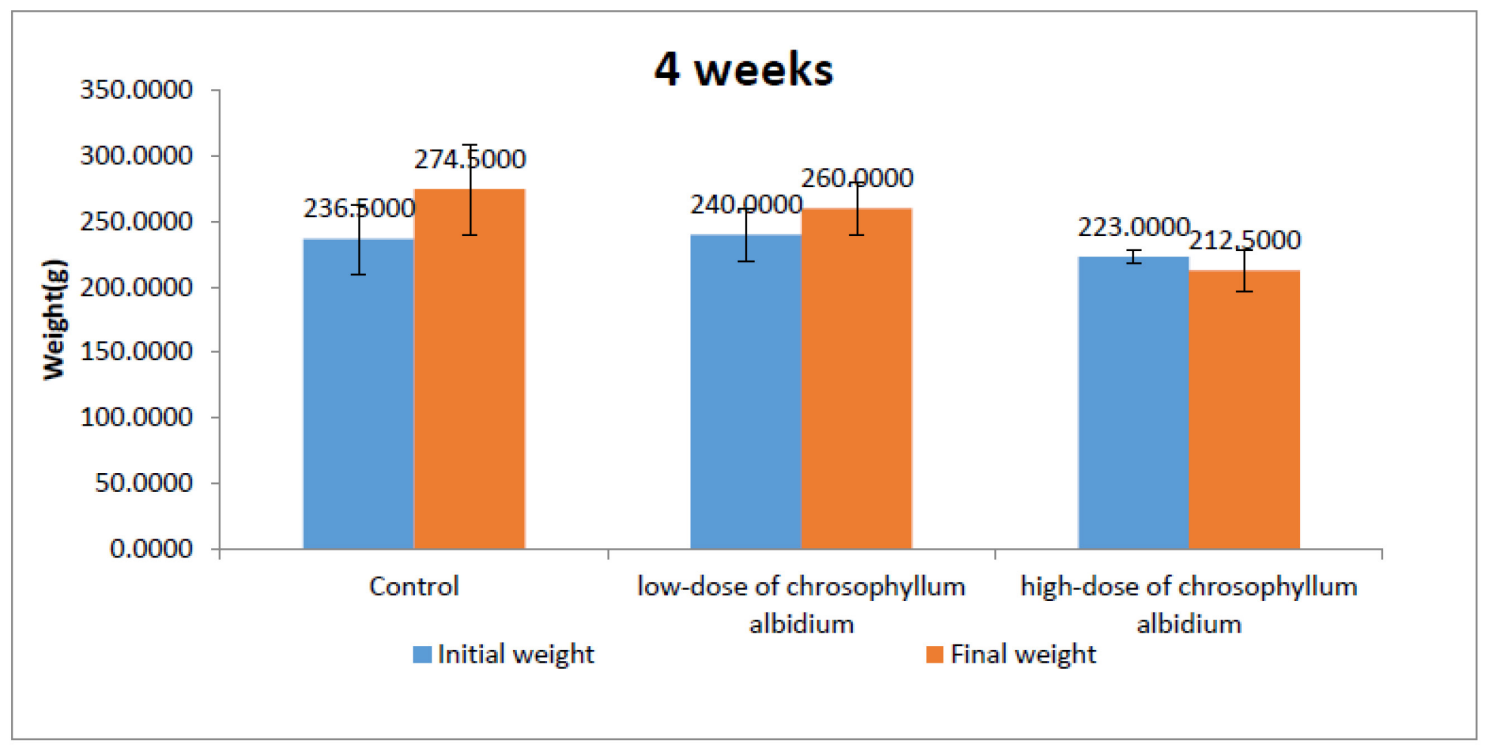

Figure 1. Effect of aqueous root extract of Chrysophyllum albidum on the initial and final body weight of the experimental rats for 4 Weeks

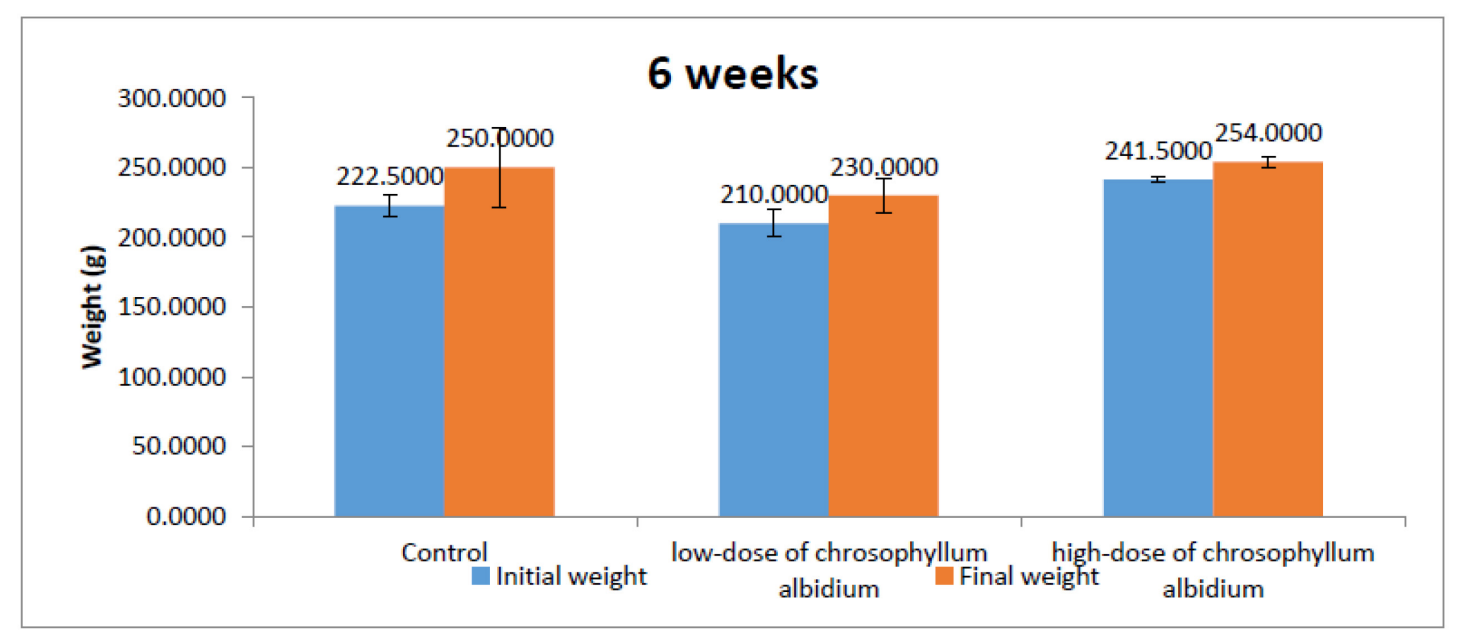

Figure 2. Effect of aqueous root extract of Chrysophyllum albidum on the initial and final body weight of the experimental rats for 6 Weeks 


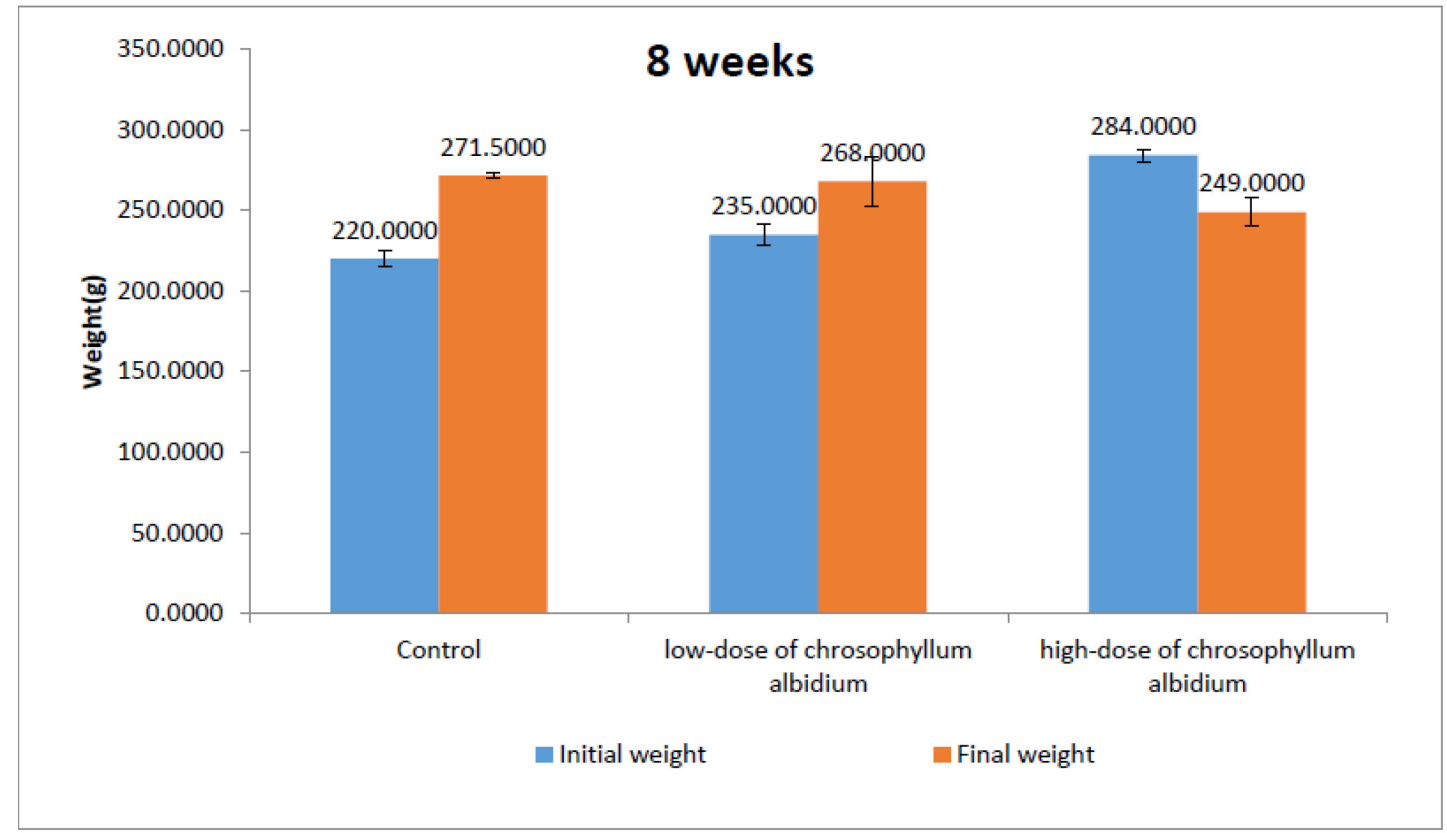

Figure 3. Effect of aqueous root extract of Chrysophyllum albidum on the initial and final body weight of the experimental rats for 8 Weeks

At the 4th week (day 28), 6th week (day 42) and 8th week (day 56) of the experiment (Fig 1, $2 \& 3$ ), animals in the three groups showed both decrease and increase in body weight at varying periods of the experiment. There was no significant difference $(p>0.05)$ between the initial and final body weight of the treated group as compared to the control group.

\section{Effect on organ weight}

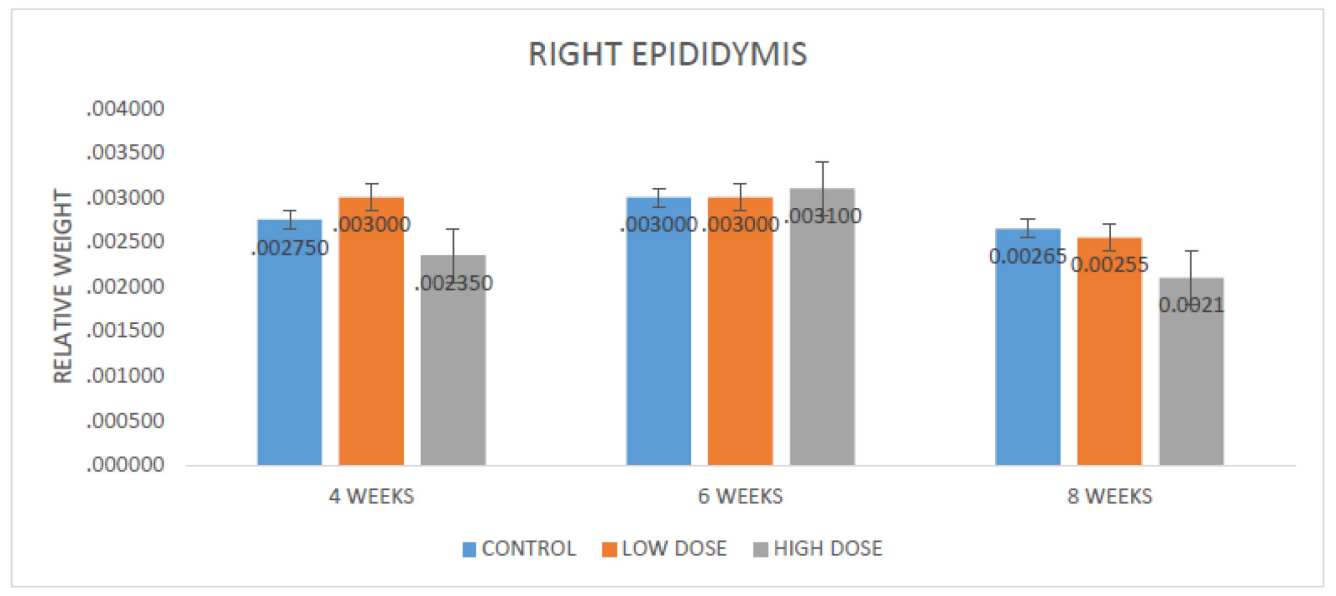

Figure 4. Effect of aqueous root extract of Chrysophyllum albidum on the relative organ weight of the right epididymis of the experimental rats 


\section{LEFT EPIDIDYMIS}

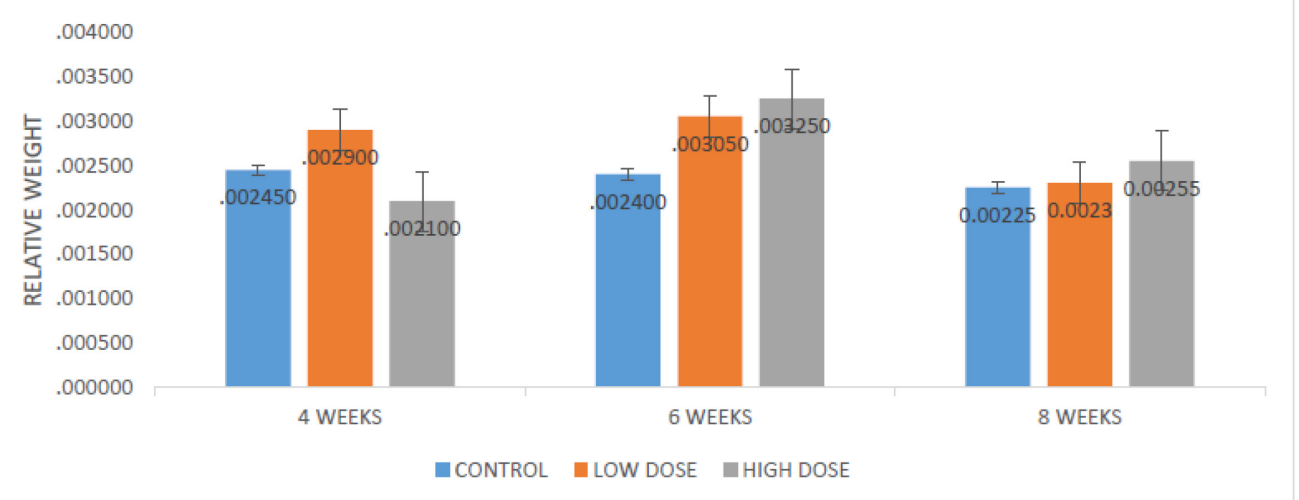

Figure 5. Effect of aqueous root extract of Chrysophyllum albidum on the relative organ weight of the left epididymis of the experimental rats

There was no significant difference $(\mathrm{p}>0.05)$ in changes in the relative organ (right and left epididymis) weight between the treated groups and the control group, at the 4th, 6th and 8th week of the experiment (Fig. $4 \& 5$ ).

\section{Effect on total sperm count}

\section{TOTAL SPERM COUNT}

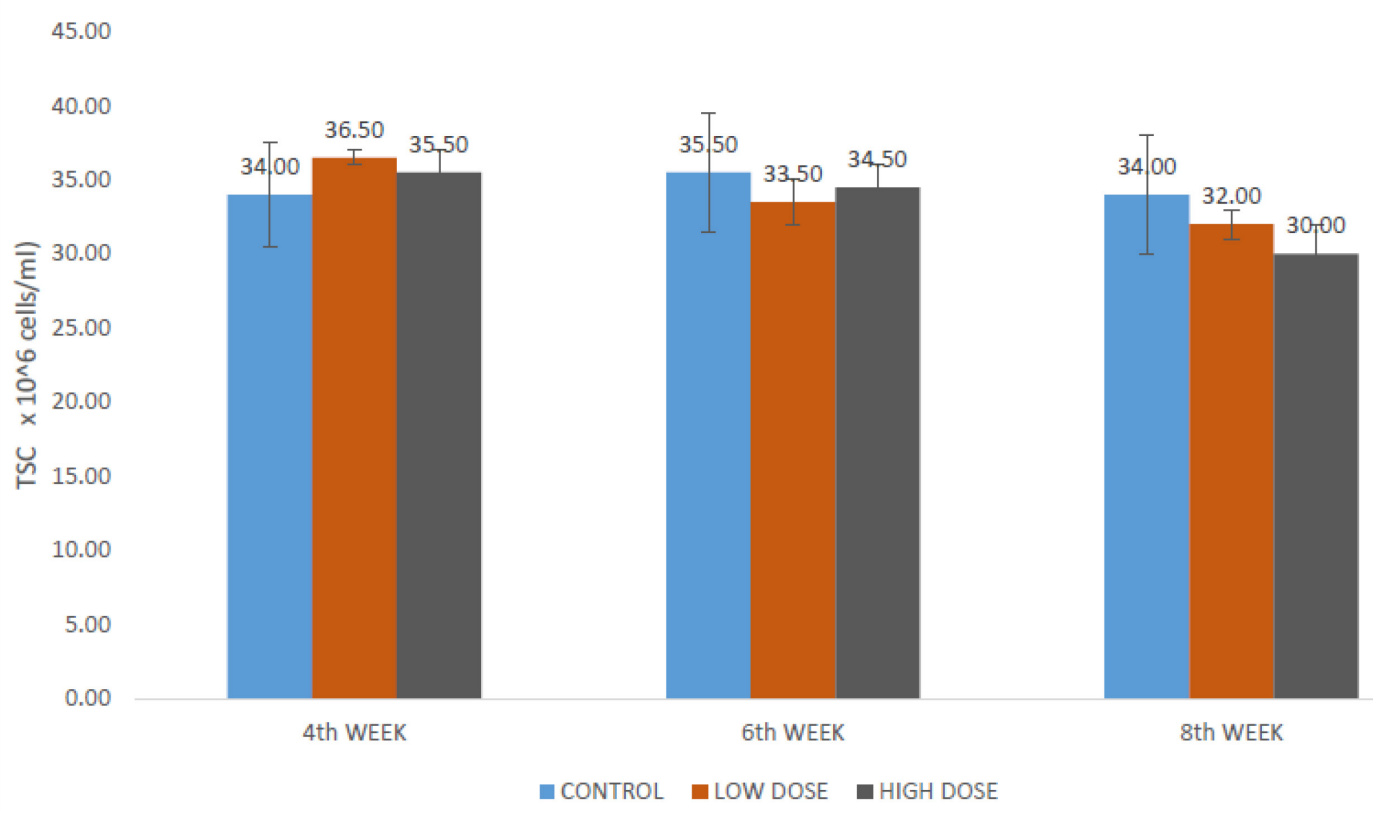

Figure 6. Effect of aqueous root extract of Chrysophyllum albidum on the total sperm count of the experimental rats at the 4th week (day 28), 6th week (day 42) and 8th week (day 56) of the experiment

At the 4th week of extract administration (Fig. 6), there was no significant difference $(p>0.05)$ between the total sperm count of the rats in the control group A1 $(34.00 \pm 4.00 \mathrm{x}$ $106 \mathrm{cells} / \mathrm{ml}$ ) and those of the treated groups (B1: $36.50 \pm 1.5 \times 106$ cells $/ \mathrm{ml}$ and $\mathrm{C} 1: 35.50 \pm 3.50 \mathrm{x}$ 106 cells $/ \mathrm{ml})$.

At the 6th week (Fig. 6), the total sperm count of rats in the control group A2 $(35.50 \pm 4.00 \mathrm{x}$ 106 cells $/ \mathrm{ml})$ was not significantly different $(\mathrm{p}>0.05)$ from those in the treated groups $(\mathrm{B} 2: 33.50 \pm$ $0.5 \times 106$ cells $/ \mathrm{ml}$ and $\mathrm{C} 2: 34.50 \pm 1.5 \times 106$ cells $/ \mathrm{ml})$. 
At the 8th week of administration (Fig. 6), the total sperm count of rats in the control group A3 $(34.00 \pm 2.00 \times 106$ cells $/ \mathrm{ml})$ was not significantly different $(\mathrm{p}>0.05)$ from those in the treated groups (B3: $32.00 \pm 1.0 \times 106$ cells $/ \mathrm{ml}$ and C3: $30.00 \pm 2.00 \times 106$ cells $/ \mathrm{ml})$.

\section{Effect on sperm motility}

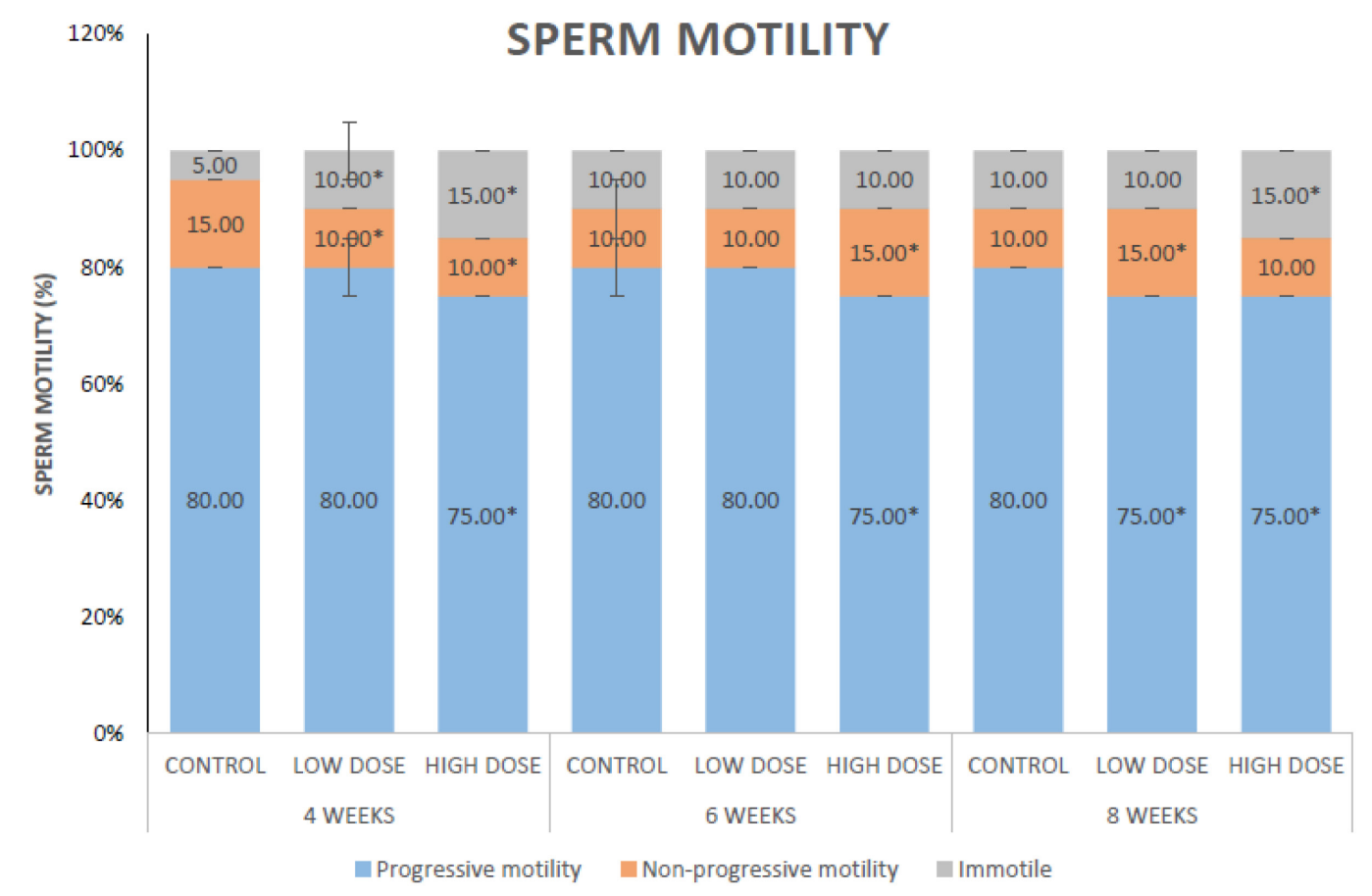

Figure 7. Effect of aqueous root extract of Chrysophyllum albidium on Sperm Motility (Progressive, Non-progressive and immotile) of the experimental Rats for 4 weeks, 6weeks and 8 weeks. Bars represent Mean \pm SEM. Superscript * indicate means with significant $(\mathrm{P}<0.05)$ difference compared to group A (Control)

At the 4th week (day 28) of extract administration, there was no significant difference $(\mathrm{P}>0.05)$ between the number of progressively motile sperm cells of rats in subgroup B1treated with low dose $(80.00 \pm 0.00 \%)$ and that of the control rats A1 $(80.00 \pm 0.00 \%)$. However, there was a significant $(\mathrm{P}<0.05)$ decrease in the number of progressively motile sperm cells in sub group $\mathrm{C} 1$ treated with high dose $(75.00 \pm 5.00 \%)$ than the control A1 $(80.00 \pm 0.00 \%)$. Also, there were significant $(\mathrm{P}<0.05)$ decreases in the percentages of non-progressively motile sperm of rats in subgroup B1 $(10.00 \pm 0.00 \%)$ and subgroup C1 $(10.00 \pm 0.00 \%)$ than those of rats in the control group A1 $(15.00 \pm 0.00 \%)$. The administration of the extract for 4 weeks caused significant $(\mathrm{P}<0.05)$ increases in the percentages of immotile sperm of the experimental rats in subgroups B1 and $\mathrm{C} 1(10.00 \pm 5.00 \%$ and $15.00 \pm 0.00 \%$ respectively) than those of the control rats $\mathrm{A} 1$ $(5.00 \pm 0.00 \%)$ (Fig. 7).

At week 6 (day 42) of the experiment, administration of the extract did not result in any significant $(\mathrm{P}>0.05)$ difference in the number of progressively motile sperm cells of rats in subgroup B2 treated with low dose of the extract $(80.00 \pm 0.00 \%)$ as compared with the control A2 $(80.00 \pm 0.00 \%)$. Administration of the extract resulted in a significant $(p<0.05)$ decrease in the number of progressively motile sperm cells in sub group $\mathrm{C} 2$ treated with high dose $(75.00 \pm 5.00 \%)$ as compared to the control A2 $(80.00 \pm 0.00 \%)$. At the 6th week of extract administration, the percentage of non-progressively motile sperm cells in subgroup B2 $(10.00 \pm 0.00 \%)$ was not significantly different $(\mathrm{P}>0.05)$ from that of the control A2 $(10.00 \pm 0.00 \%)$ while that of subgroup $\mathrm{C} 2(15.00 \pm 5.00 \%)$ was significantly $(\mathrm{P}<0.05)$ higher than that of the control group A2 $(10.00 \pm 0.00 \%)$. There was no significant difference $(\mathrm{P}>0.05)$ in the percentages of immotile sperm cells of rats in subgroup B2 and C2 $(10.00 \pm 5.00 \%$ and 
$10.00 \pm 0.00 \%$ respectively) compared with that of the control $(10.00 \pm 0.00 \%)$ after 6 weeks of extract administration (Fig. 7).

In Fig. 7, administration of extract of Chrysophyllum albidium for 8 weeks resulted in significant $(\mathrm{P}<0.05)$ decreases in the number of progressively motile sperm cells of rats in subgroup B3 $(75.00 \pm 0.00 \%)$ and C3 $(75.00 \pm 0.00 \%)$ as compared with the control group A3 $(80.00 \pm 0.00 \%)$. Also, the administration of the extract resulted in a significant $(\mathrm{P}<0.05)$ increase in the percentage of non-progressively motile sperm cells in subgroup B3 $(15.00 \pm 5.00 \%)$ and no significant difference $(\mathrm{P}>0.05)$ in subgroup $\mathrm{C} 3(10.00 \pm 0.00 \%)$ as compared with the control group A3 (10.00 $\pm 0.00 \%)$. Although, as compared with control group A3 $(10.00 \pm 0.00 \%)$, there was no significant difference $(\mathrm{P}>0.05)$ in the percentage of immotile sperm cells of rats in subgroup B3 $(10.00 \pm 0.00 \%)$, there was a significant $(\mathrm{P}<0.05)$ increase in subgroup C3 treated with high dose $(15.00 \pm 5.00 \%)$.

\section{Effect on sperm morphology}

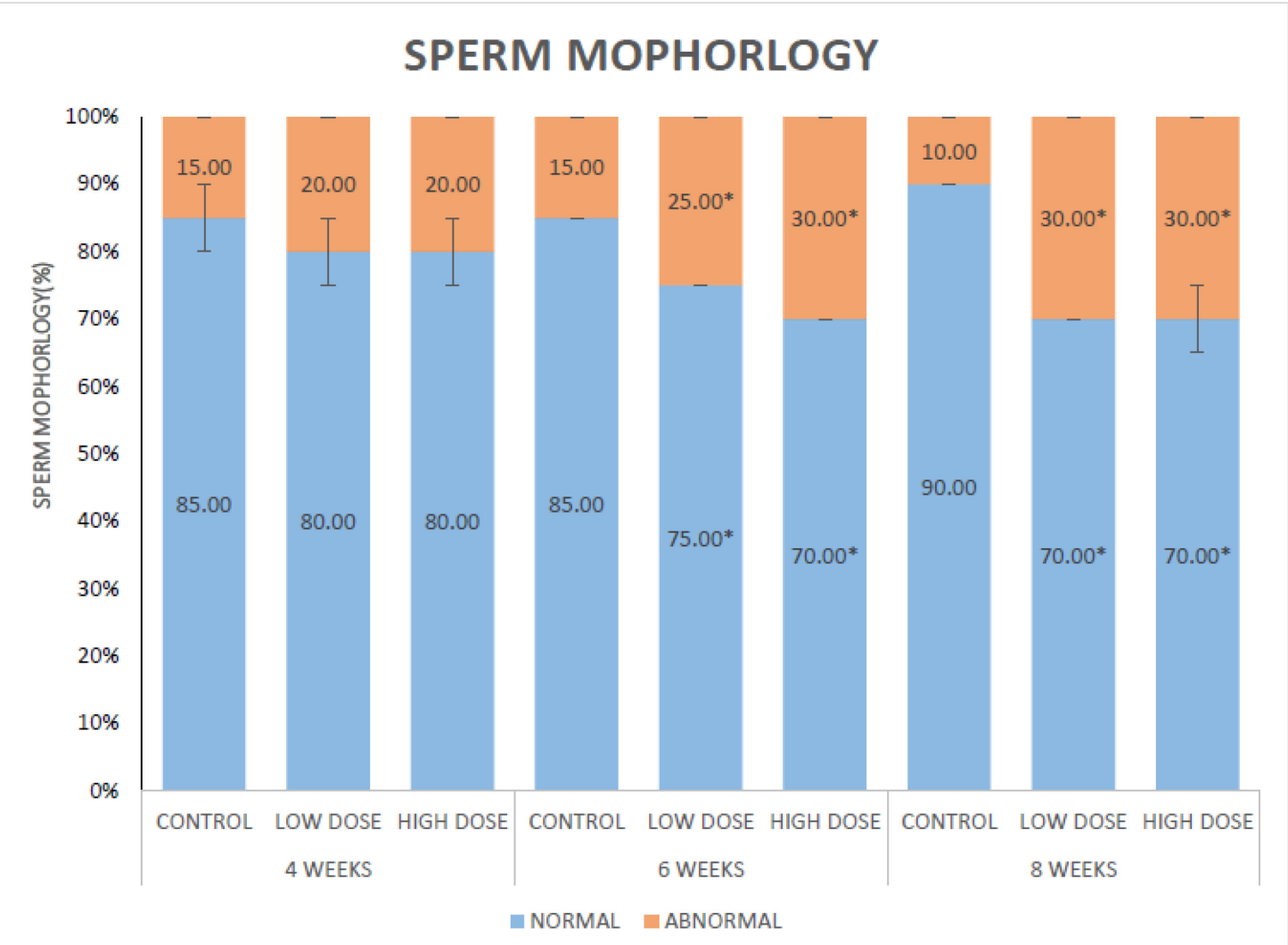

Figure 8. Effect of aqueous root extract of Chrysophyllum albidium on the Sperm Morphology of the experimental Rats at the 4th week (day 28), 6th week (day 42) and 8th week (day 56) of the experiment. Bars represent Mean \pm SEM. Superscript * indicate means with significant $(\mathrm{P}<0.05)$ difference compared to group A

In Fig. 8, after administration of aqueous root extract of Chrysophyllum albidium for 4 weeks, there was no significant difference $(\mathrm{P}>0.05)$ in the number of morphologically normal sperm cells of test rats in subgroups B1 $(36.50 \pm 1.5 \times 106 \mathrm{cells} / \mathrm{ml} ; 80.00 \pm 0.00 \%)$ and $\mathrm{C} 135.50 \pm 3.50 \mathrm{x}$ 106 cells $/ \mathrm{ml} ; 80.00 \pm 0.00 \%)$ compared to those of the control subgroup A1 $(34.00 \pm 4.00 \mathrm{x}$ 106 cells $/ \mathrm{ml} ; 85.00 \pm 5.00 \%)$. Also, there was no significant difference $(\mathrm{P}>0.05)$ in the number of morphologically abnormal sperm cells of test rats in subgroups B1 $(36.50 \pm 1.5 \mathrm{x} 106 \mathrm{cells} / \mathrm{ml}$; $20.00 \pm 0.00 \%)$ and $\mathrm{C} 1(35.50 \pm 3.50 \times 106 \mathrm{cells} / \mathrm{ml} ; 20.00 \pm 0.00 \%)$ compared to those in control subgroup A1 $(34.00 \pm 4.00 \times 106 \mathrm{cells} / \mathrm{ml} ; \mathrm{I} 5.00 \pm 5.00 \%)$.

Administration of aqueous root extract of Chrysophyllum albidium for 6 weeks (Fig. 8) resulted in significant $(\mathrm{P}<0.05)$ decreases in number of morphologically normal sperm cells of rats in subgroup B2 treated with low dose of the extract $(36.50 \pm 1.5 \times 106 \mathrm{cells} / \mathrm{ml} ; 75.00 \pm 5.00 \%)$ and 
subgroup C2 treated with high dose of the extract $(34.50 \pm 1.5 \times 106$ cells $/ \mathrm{ml} ; 70.00 \pm 0.00 \%)$ as compared to the control subgroup A2 $(35.50 \pm 4.00 \times 106$ cells $/ \mathrm{ml} ; 85.00 \pm 5.00 \%)$. Also, it resulted in significant $(\mathrm{P}<0.05)$ increases in the number of morphologically abnormal sperm cells of rats in test subgroups B2 $(36.50 \pm 1.5 \times 106 \mathrm{cells} / \mathrm{ml} ; 25.00 \pm 0.00 \%)$ and C2 $(34.50 \pm 1.5 \times 106 \mathrm{cells} / \mathrm{ml}$; $30.00 \pm 0.00 \%)$ as compared to the control subgroup A2 $(35.50 \pm 4.00 \times 106$ cells $/ \mathrm{ml} ; 15.00 \pm 5.00 \%)$.

At the 8th week of experiment, administration of the extract caused significant $(p<0.05)$ decreases in the number of morphologically normal sperm cells of rats in test subgroups B3 treated with low dose $(32.00 \pm 1.0 \times 106$ cells $/ \mathrm{ml} ; 70.00 \pm 0.00 \%)$ and $\mathrm{C} 3$ treated with high dose $(30.00 \pm 2.00 \times 106 \mathrm{cells} / \mathrm{ml} ; 70.00 \pm 0.00 \%)$ as compared to the control subgroup A3 (34.00 \pm $2.00 \times 106$ cells $/ \mathrm{ml} ; 90.00 \pm 0.00 \%)$. Also, there were significant $(\mathrm{P}<0.05)$ decreases in the number of morphologically abnormal sperm cells of rats in the test subgroups B3 $(32.00 \pm 1.0 \mathrm{x}$ 106 cells $/ \mathrm{ml} ; 30.00 \pm 0.00 \%)$ and $\mathrm{C} 3(30.00 \pm 2.00 \times 106 \mathrm{cells} / \mathrm{ml} ; 30.00 \pm 0.00 \%)$ as compared to rats in the control subgroup A3 (34.00 $2.00 \times 106$ cells $/ \mathrm{ml} ; 10.00 \pm 0.00 \%)$.

\section{Effect on sperm morphology}

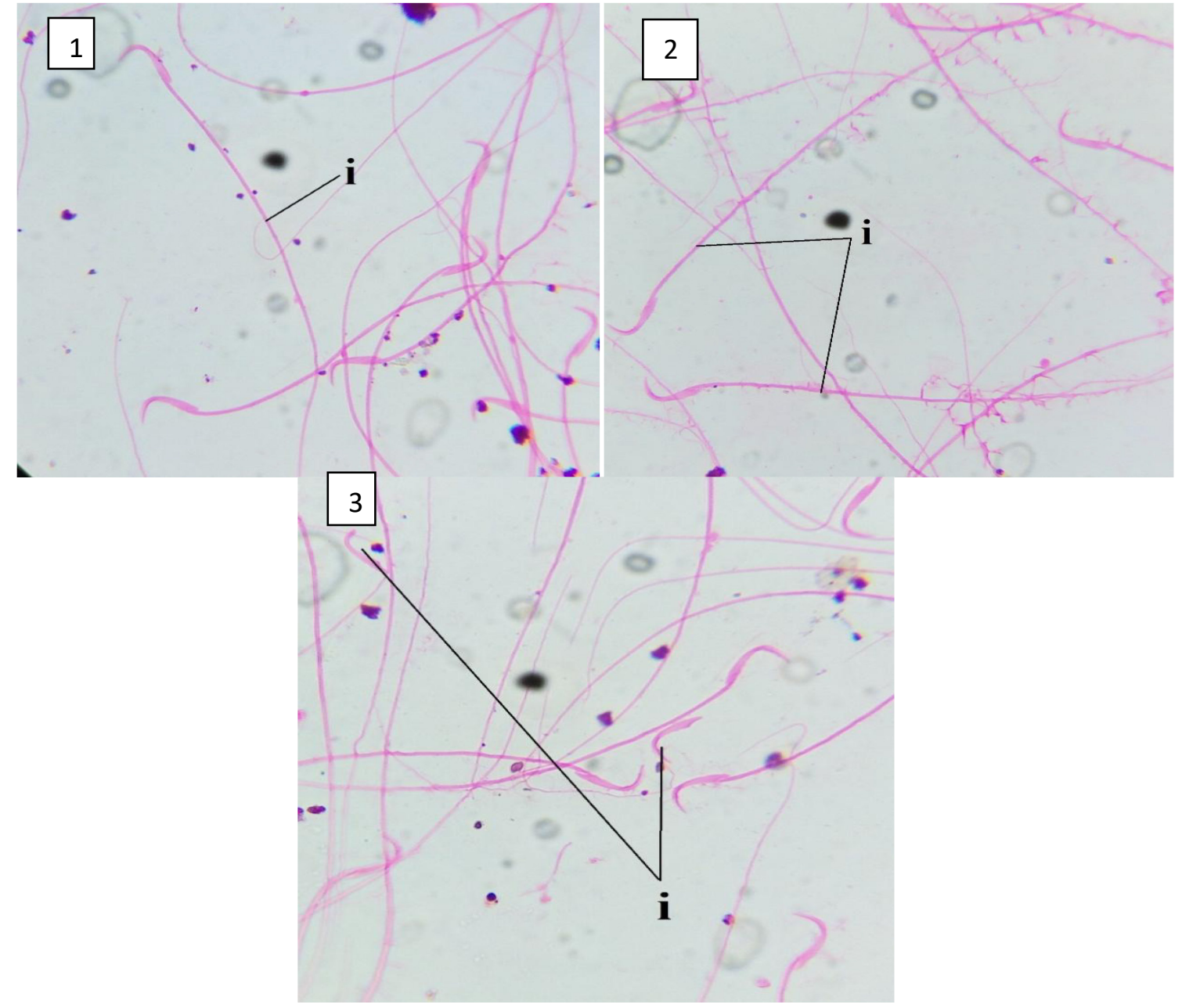

Figure 9. Micrograph of sperm morphology of the experimental rats at week 4 (day 28) of extract administration: Plate 1; Group A1 rats (control) showing normal spermatozoa (i) $\times 1000$. Plate 2: Group B1 rats treated with $250 \mathrm{mg} / \mathrm{kg}$ body weight of aqueous root extract of Chrysophyllum albidium, showing normal spermatozoa (i) $\times 1000$. Plate 3: Group C1 rats treated with $500 \mathrm{mg} / \mathrm{kg}$ body weight of aqueous root extract of Chrysophyllum albidium showing (i) abnormal sperm cells, tailless spermatozoa $\times 1000$ 


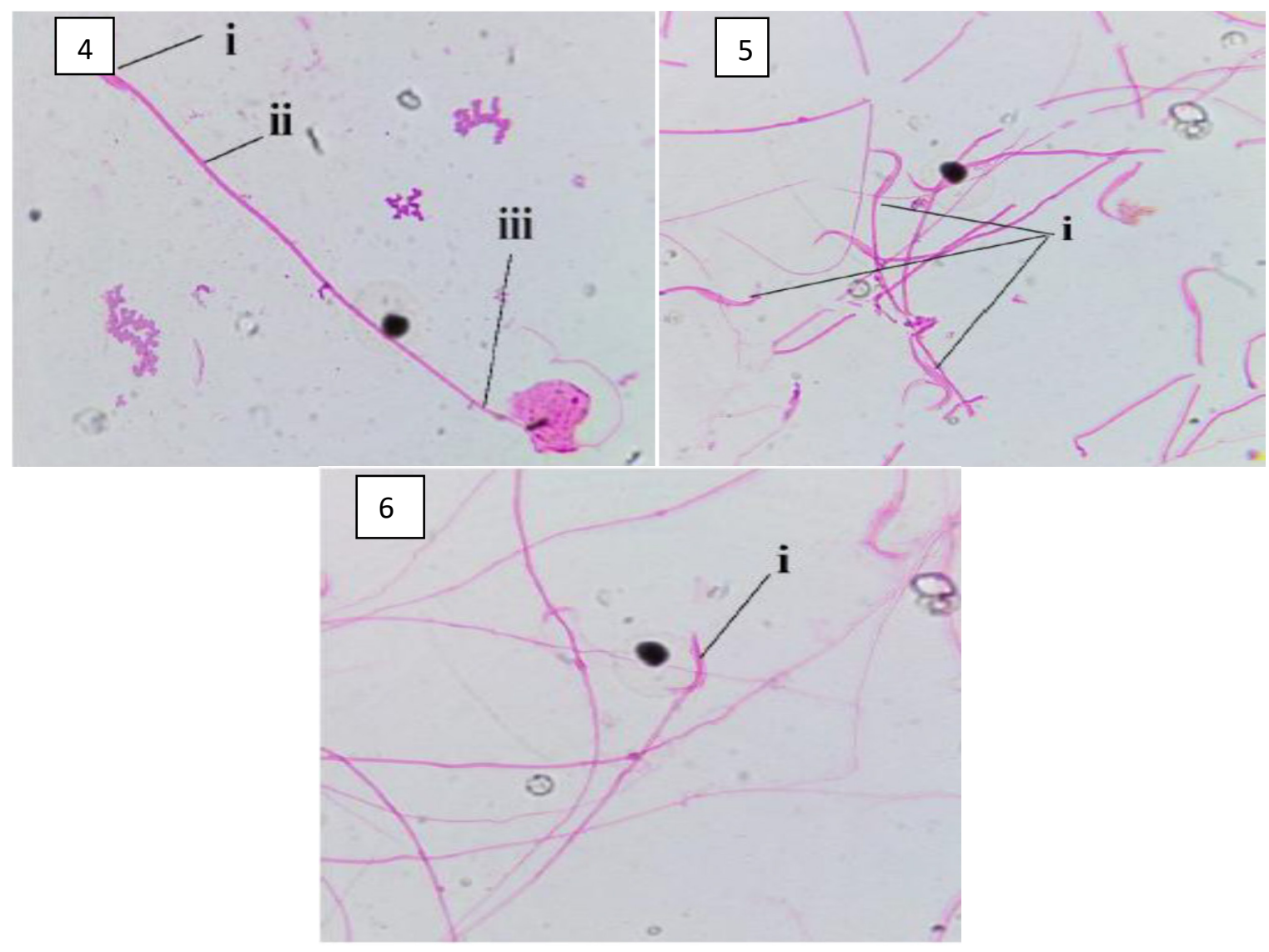

Figure 10. Micrograph of sperm morphology of the experimental rats at week 6 (day 42) of extract administration: Plate 4: Group A2 (control) showing normal spermatozoa (i) Head (ii) body (iii) Tail $\times 1000$. Plate 5: Group B2 treated with $250 \mathrm{mg} / \mathrm{kg}$ body weight of aqueous root extract of Chrysophyllum albidium, showing (i) degenerated spermatozoa debris $\times 1000$. Plate 6: Group C2 treated with $500 \mathrm{mg} / \mathrm{kg}$ body weight of aqueous root extract of Chrysophyllum albidium, showing (i) bent headed sperm cell $\times 1000$ 

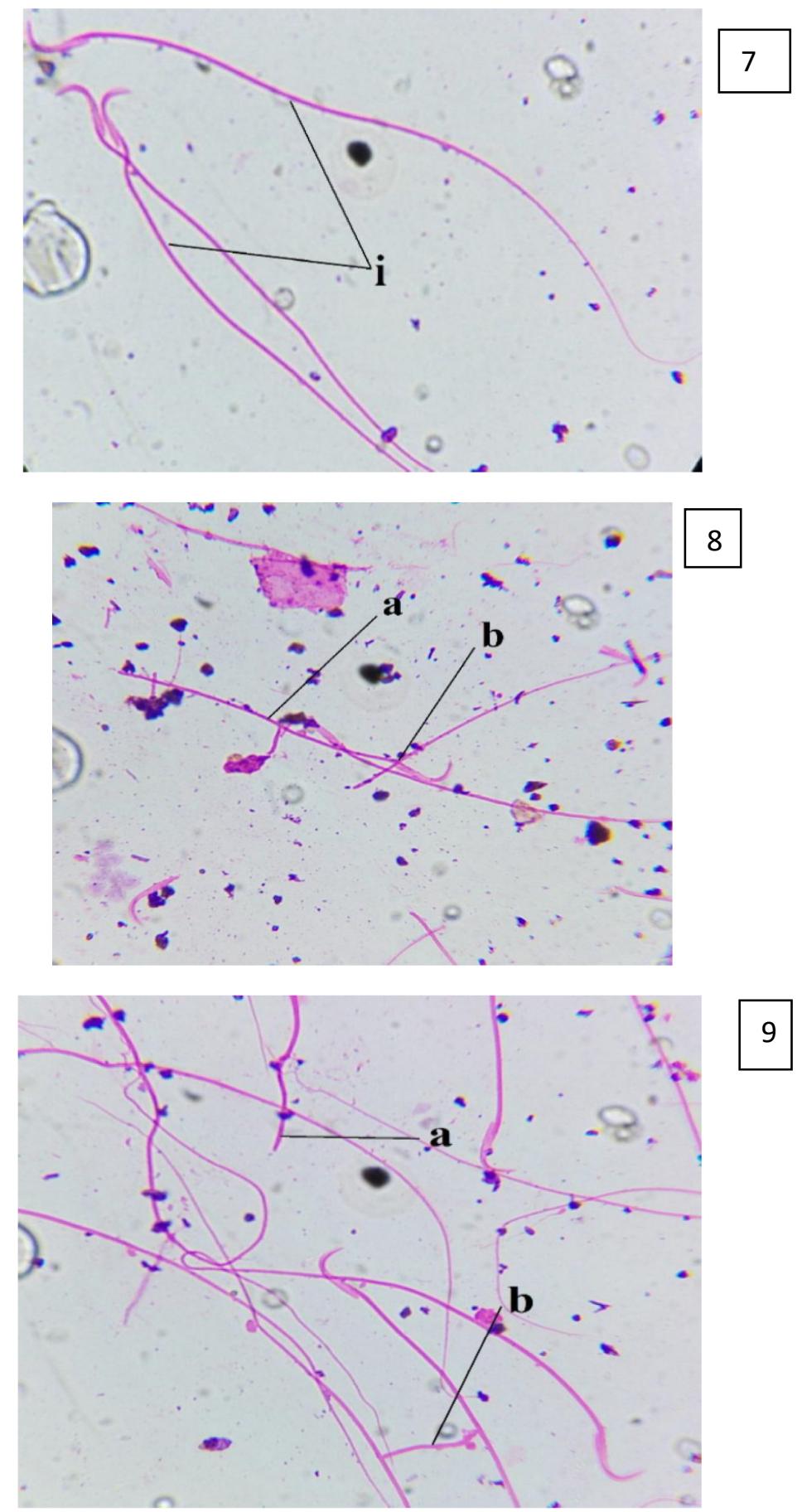

Figure 11. Micrograph of sperm morphology of the experimental rats at week 8 (day 56) of extract administration: Plate 7: Group A3 (control) showing normal spermatozoa (i) $\times 1000$. Plate 8: Group B3 treated with $250 \mathrm{mg} / \mathrm{kg}$ body weight of aqueous root extract of Chrysophyllum albidium, showing (a) short tailed sperm cell (b)Headless sperm cell $\times 1000$. Plate 9: Group C3 treated with $500 \mathrm{mg} / \mathrm{kg}$ body weight of aqueous root extract of Chrysophyllum albidium, showing (a) headless sperm cells (b) degenerated sperm cell debris 


\section{Effect on histology of epididymis}

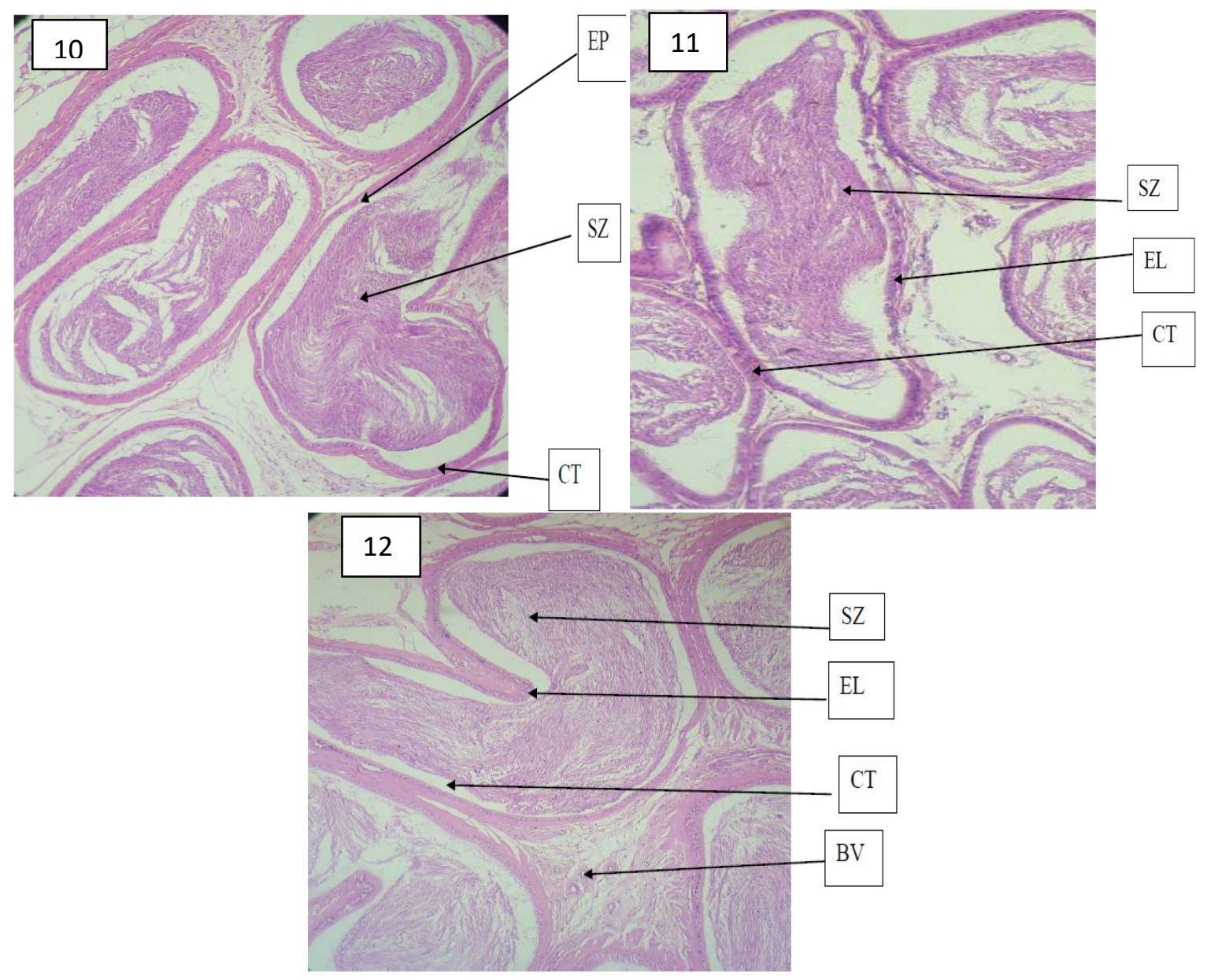

Figure 12. Photomicrograph of Epididymis ( $\mathrm{H} \& \mathrm{E} \mathrm{x} 400)$ of the experimental rats at week 4 (day 28) of extract administration. PLATE 10: Group A1 (control) rats: features seen include clumps of spermatozoa (SZ), connective tissue (CT) and epithelial lining of the epididymis (EL). Plate 11: Group B1 rats treated with $250 \mathrm{mg} / \mathrm{kg}$ body weight of aqueous root extract of Chrysophyllum albidium: features seen include clumps of spermatozoa (SZ), connective tissue (CT) and epithelial lining of the epididymis (EL). Plate 12; Group C1 rats treated with $500 \mathrm{mg} / \mathrm{kg}$ body weight of aqueous root extract of Chrysophyllum albidium: features seen include clumps of spermatozoa (SZ), connective tissue (CT) blood vessels(BV) and epithelial lining of the epididymis (EL) 

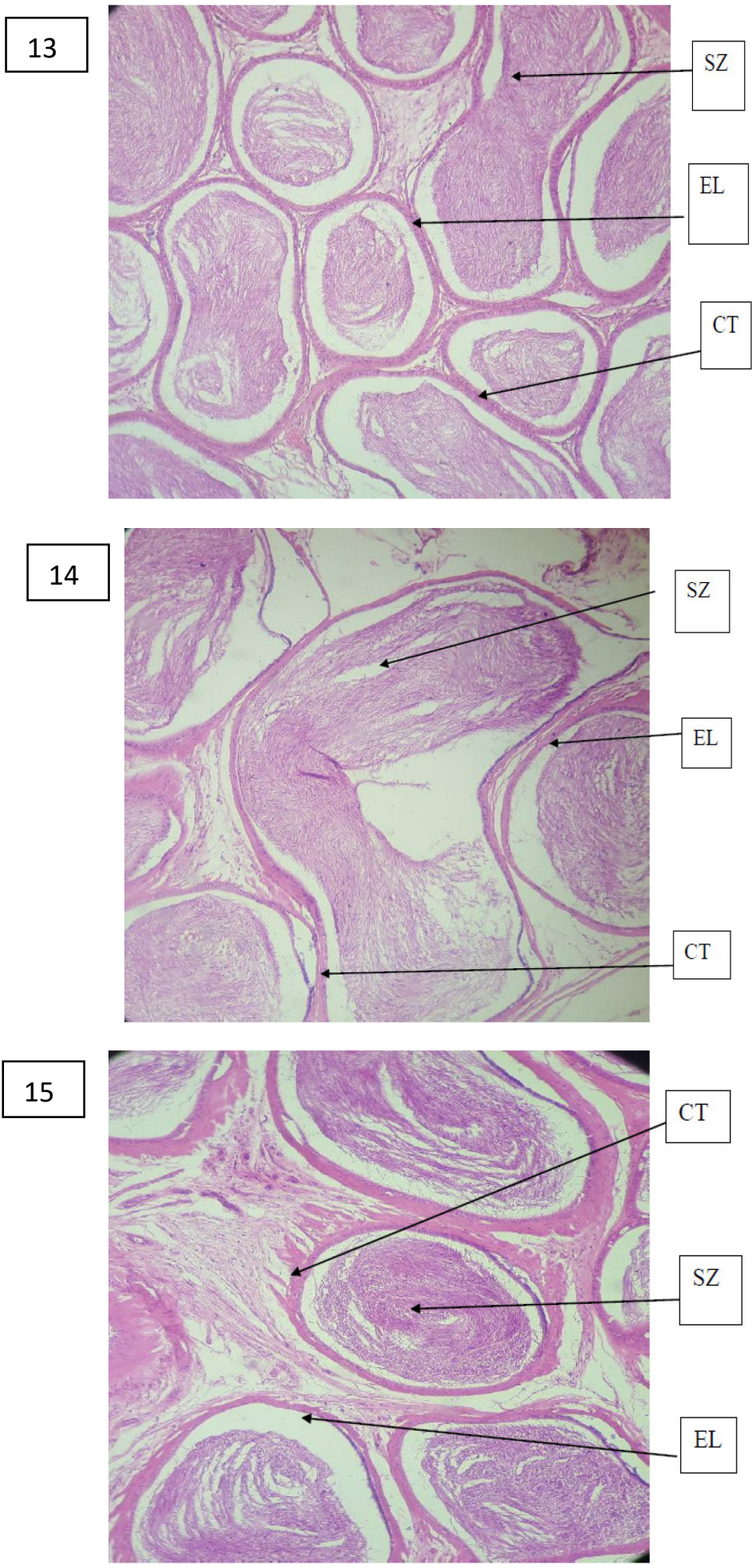

Figure 13. Photomicrograph of Epididymis $(\mathrm{H} \& \mathrm{E} x \mathrm{400})$ of the experimental rats at week 6 (day 42) of extract administration. Plate 13: Group A2 rats (control): features seen include clumps of spermatozoa (SZ), connective tissue (CT) and epithelial lining of the epididymis (EL). Plate 14: Group B2 rats treated with $250 \mathrm{mg} / \mathrm{kg}$ body weight of aqueous root extract of Chrysophyllum albidium: features seen include clumps of spermatozoa (SZ), connective tissue (CT) and epithelial lining of the epididymis (EL). Plate 15: Group C2 rats treated with $500 \mathrm{mg} / \mathrm{kg}$ body weight of aqueous root extract of Chrysophyllum albidium: features seen include clumps of spermatozoa (SZ), connective tissue (CT) and epithelial lining of the epididymis (EL) 

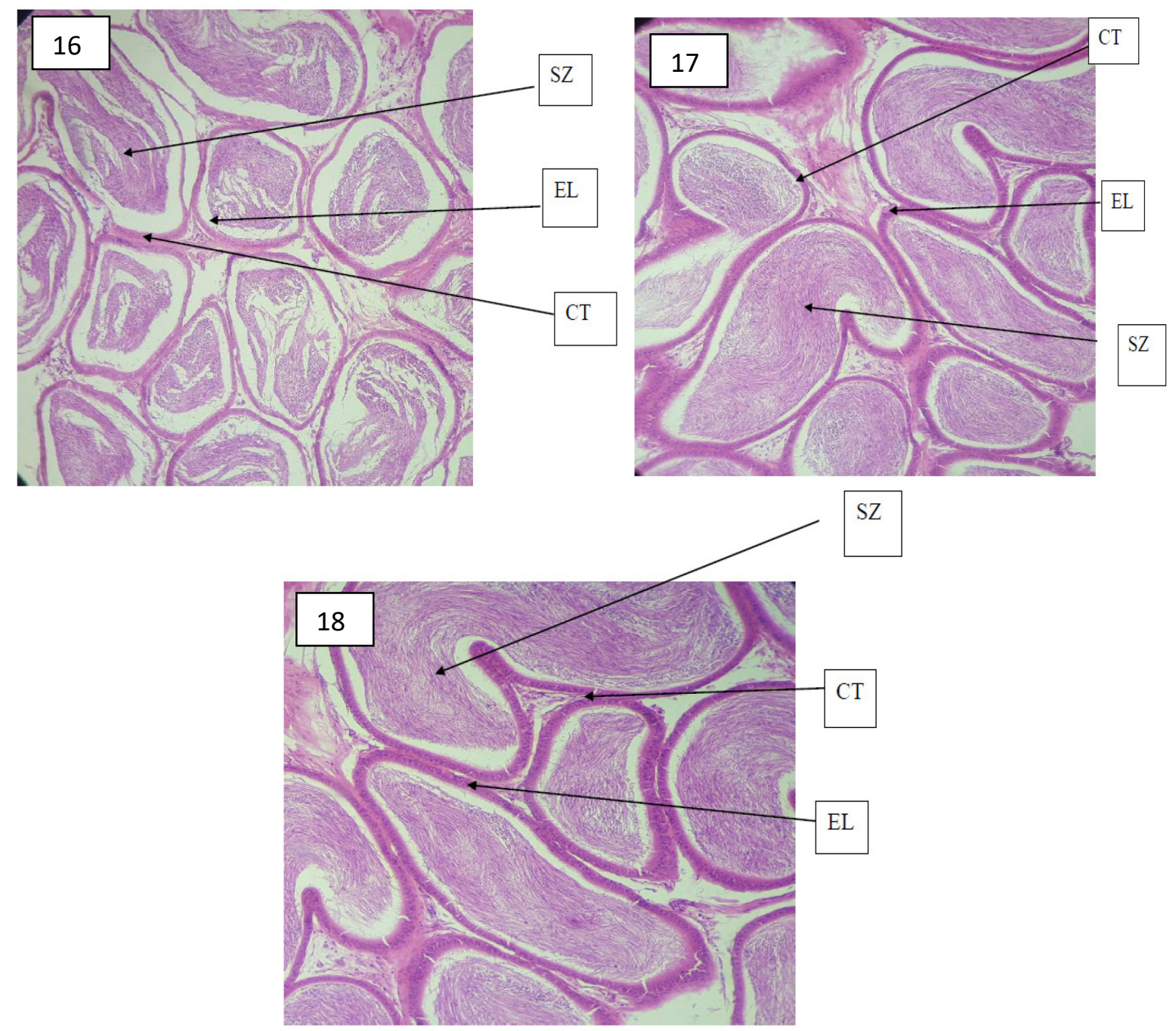

Figure 14. Photomicrograph of Epididymis $(H \& E x 400)$ of the experimental rats at week 8 (day 56) of extract administration. Plate 16: Group A3 (control) rats: features seen include clumps of spermatozoa (SZ), connective tissue (CT) and epithelial lining of the epididymis (EL). Plate 17: Group B3 rats treated with $250 \mathrm{mg} / \mathrm{kg}$ body weight of aqueous root extract of Chrysophyllum albidium: features seen include clumps of spermatozoa (SZ), connective tissue (CT) and epithelial lining of the epididymis (EL). Plate 18: Group C3 rats treated with $500 \mathrm{mg} / \mathrm{kg}$ body weight of aqueous root extract of Chrysophyllum albidium: features seen include clumps of spermatozoa (SZ), connective tissue (CT) and epithelial lining of the epididymis (EL)

There were no significant histological changes in the epididymis of the experimental rats in all the treated groups, at different doses and duration, as compared to the rats in the control group.

\section{Discussion}

The male reproductive system is a complex system which consists of the hypothalamus, anterior pituitary gland, the testes and glands like the epididymis. These structures work together to maintain the potency, fertility, and male secondary sexual characteristics [15]. Spermatogenesis, the first part of sperm production which includes stem cell mitosis and meiosis, is the biological process of gradual transformation of germ cells into spermatozoa over an extended period of time within the seminiferous tubules of the testis [16]. While spermiogenesis is the final differentiation process which occurs in the haploid male germ cells [17], sperm cells are produced in the seminiferous tubules at a rate of about $2 \times 108$ per day in the young adult. However, spermatogenic process in rats requires 53 days, out of which the spermatozoa spends the last 6 to 7 days in the final transit through the epididymis. 
In this study, aqueous root extract of Chrysophyllum albidium was administered to the experimental rats for 28 days (4weeks), 42 days (6weeks) and 56 days (8weeks), at different doses. This was done to ascertain the possible dose and duration effects of Chrysophyllum albidium on the sperm characteristics of the rats, as well as changes in body and organ weights. Our findings show that administration of Chrysophyllum albidium did not cause significant changes in body weights and organ (testes and epididymis) weights of the experimental rats irrespective of the dose and duration of extract administration. Also, the total epididymal sperm count was not significantly affected. These findings, which correlate with non-changing histology of the epididymis, may possibly indicate that the aqueous root extract of Chrysophyllum albidium had no adverse effect on the sperm characteristics of the experimental rats.

However, the effects on sperm motility indicates that increasing dosage and duration of administration of the aqueous root extract of Chrysophyllum albidium caused increased number of non-progressive sperm cells and immotile sperm cells, and decreased number of progressive motile sperm cells. This may portend possible disruption of sperm development by the extract. Disruption in the development of sperm cells could result in the production of more immotile and none progressive motile sperm cell which therefore decreases sperm motility. Sperm morphology, a relative function of the testes, was also affected by increasing dose and duration of extract administration. The number of normal sperm cells decreased while the number of abnormal sperm cells increased. Abnormal development of sperm cells in the testes, possibly caused by the extract, may lead to increase abnormal sperm cells which may compromise the fertility of the experimental rats.

Histology revealed that there were no changes in the epididymis of the test rats irrespective of the dose and duration of extract administration. The epididymis has its own blood epididymis barrier [18], contains substances such as proteins and its structure is quite different from that of the testes [19]. According to Friend and Gilula [20], the zonula occludens of the epididymis is the most highly developed, even more than the testes. These factors possibly played a major role in countering the effects of the extract on the epididymis, causing it to maintain its normal histological appearance.

\section{Conclusion}

Administration of aqueous root extract of Chrysophyllum albidium resulted in dose and duration dependent adverse effects on sperm motility and morphology which may compromise the fertility of the experimental rats.

\section{List of Abbreviations}

$\mathrm{PM}=$ Progressive Motility, NPM = Non Progressive Motility, IM = Immotile, NSC $=$ Normal Sperm Cells, ASC = Abnormal Sperm Cells, CT = Connective Tissue, EL = Epithelial Lining of the Epididymis, $\mathrm{SZ}=$ Spermatozoa, BV = Blood Vessels.

\section{Acknowledgment}

The Authors acknowledge the Department of Anatomy, School of Basic Medical Sciences, College of Medical Sciences, University of Benin, (Edo State, Nigeria) for providing the necessary laboratory facilities. We also wish to state that the research was self-funded.

\section{Conflict of interest}

The authors declare no conflict of interest. 


\section{References}

[1] I.S. Allag, K. Rangari, Extragenomic action of steroids on spermatozoa: prospect for regulation of fertility, Health Popul. 25 (2002) 38-44.

[2] S.K. Sharma et al., Mechanism of action of NIM-76: A novel vaginal contraceptive from neem oil, Contraception. 54 (1996) 373-378.

[3] T. Paul et al., Brain response to visual sexual stimuli in heterosexual and homosexual males, Hum. Brain Mapp. 29 (2006) 726-735.

[4] K.N. Eze, Antifertility effects of ethanolic extract of Xylopia aethiopica on male reproductive organ of Wistar rats, American Journal of Medicine and Medical Sciences. 2(1) (2012) 12-15.

[5] B.J. Okoli, O.S. Okere, Antimicrobial activity of the phytochemical constituents of Chrysophyllum albidum G.Don Holl. (African Star apple), Plant. Journal of Research in National Development. 8(1) (2010).

[6] T.O. Idowu et al., Biochemical and behavioural effects of eleagnine from Chrysophyllum albidum, Journal of Biological Sciences. 6 (2006) 1029-1034.

[7] S.A. Adisa et al., Vitamin C, protein and mineral content of African apple (Chrysophillum albidum), in: Proceedings of the 18th Annual Conference of NIST; 2000, pp. 141-146.

[8] C.A. Onyeka et al., Effects of ethanolic root bark extract of Chrysophyllum albidum on serum superoxide dismutase, catalase and malondialdehyde in rat, International Journal of Pharmaceutical Science and Research. 3(3) (2012) 347-351.

[9] E.O. Adewoye et al., The antimicrobial and kill kinetics of Chrysophyllum albidum stem bark extracts, European Journal of Scientific Research. 56(3) (2011) 434-444.

[10] R. Leke, Reproductive health in Cameroon, Geneva, WHO, Collaborating centre for Research in Human Reproduction, 2008.

[11] E.O. Adewoye, A.T. Salami, V.O. Taiwo, Anti-plasmodial and toxicological effects of methanolic bark extract of Chrysophyllum albidum in albino mice, Journal of Physiology and Pathphysiology. 1(1) (2010) 1-9.

[12] R.A.B. Drury, E.A. Wallington, Cartelon's Histological Techniques, Oxford University Press, Oxford, 1980.

[13] D.C. Sheehan, B.B. Hrapchak, Theory and practice of histotechnology, 2nd Edition, The CV Mosby Company, St Louis. MO: C. V. Mosby Co., 1980, pp. 143-144.

[14] F.A. Ajayi, R.E. Akhigbe, Antifertility activity of Cryptolepis sanguinolenta leaf ethanolic extract in male rats, Journal of Human Reproductive Science. 5(1) (2012) 43-47.

[15] R. Starpe, Regulation of spermatogenesis, The Physiology of Reproduction. 2 (1994) 13631414.

[16] A.L. Mescher, The male reproductive system, Junqueira's Basic Histology Text And Atlas, McGraw Hill Lange. 1 (2013) 429-447.

[17] M. Gregory, G.C. Daniel, The blood-epididymis barrier and inflammation. Spermatogenesis. 4(2) (2014) e979619.

[18] F.A. Kélen, V.G. Patrick, F.B. Mainara, The epididymis: embryology, structure, function and its role in fertilization and infertility. Embryology- Updates and Highlight on classical topics; INTECH Open Access Publisher. (2012) 3-65.

[19] D.S. Friend, N.B. Gilula, Variations in tight and gap junctions in mammalian tissues, Journal of Cell Biology. 53(3) (1972) 758-776.

[20] M.A. Belsey et al., Laboratory manual for the examination of human semen and semencervical mucus interaction, Press Concern, Singapore, 1980. 